\title{
IMPLEMENTASI PENDIDIKAN BERBASIS AQIDAH PADA SISWA SD RANTO PANYANG KECAMATAN MEUREUBO KABUPATEN ACEH BARAT
}

\author{
Suroto \\ STAIN Teungku Dirundeng Meulaboh \\ suroto@staindirundeng.ac.id
}

\begin{abstract}
Abstrak
Pendidikan bukan hanya bertujuan menciptakan manusia-manusia cerdas di bidang sains, teknologi, dan intelektualitasnya, tetapi juga harus mampu menumbuhkembangkan sikap dan semangat keagamaan yang terbuka (inklusif), karena keduanya tidak dapat dipisahkan.Berdasarkan hal tersebut mendorong penulis untuk membahasnya dengan judul "SD Ranto Panyang Barat Kecamatan Meureubo Kabupaten Aceh Barat".Penelitian ini bertujuan pertama untuk mengetahuiimplementasi pendidikan berbasis aqidah pada siswa kelas I SDN Ranto Panyang,.Penelitian skripsi ini menggunakan metode deskripsi analisis dengan jenispenelitian lapangan (field research) dan ditunjang oleh referensi-referensi yangberkaitan dengan tema yang dibahas (library research). Sampel dari penelitian ini adalah 27 murid kelas I dan guru SDN Ranto Panyang. Analisis data dilakukan dengan cara memeriksa kuisioner yang telah dijawab oleh murid sebagai responden, mengumpulkan hasil wawancara kemudian menghitung frekuensi dan persentase dari setiap alternatif jawaban. Hasil penelitian menunjukkan bahwaimplementasi Pendidikan Berbasis Aqidah pada Siswa Kelas I SDN Ranto Panyang berjalan dengan baik. Implementasi pendidikan berbasis aqidah dengan menghubungkan materi pelajaran dengan nilai-nilai aqidah, dan menjelaskan nilai-nilai aqidah itu.
\end{abstract}

Kata Kunci : Implementasi, Pendidikan, Aqidah

\begin{abstract}
Education is not only aimed at creating intelligent human beings in the fields of science, technology, and intellect, but also must be able to cultivate an open (inclusive) religious attitude and spirit, because the two cannot be separated. Based on this, it encourages the author to discuss it with the title "SD Ranto Panyang Barat, Meureubo District, West Aceh Regency". This study aims first to determine the implementation of aqidah-based education in grade I students at SDN Ranto Panyang. This thesis research uses a descriptive analysis method with the type of field research (field research) and is supported by references related to the themes discussed (library research). The samples of this study were 27 first grade students and teachers of SDN Ranto Panyang. Data analysis was carried out by examining the questionnaires that had been answered by students as respondents, collecting the results of the interviews and then calculating the frequency and percentage of each alternative answer. The results showed that the implementation of Aqidah-Based Education in Grade I Students at SDN Ranto Panyang went well. Implementation of aqidah-based education by linking subject matter with aqidah values, and explaining those aqidah values.
\end{abstract}

Keywords: Implementation, Education, Aqidah 


\section{PENDAHULUAN}

Undang-Undang No. 20 Tahun 2003 tentang sistem pendidikan di Indonesia terdiri dari pendidikan anak usia dini, pendidikan dasar, pendidikan menengah, dan pendidikan tinggi yang keseluruhannya merupakan kesatuan yang sistemik. Pendidikan Anak Usia Dini (PAUD) diselenggarakan sebelum jenjang pendidikan dasar. Departemen Pendidikan Nasional (2003: 17) Perlu disadari bahwa masa-masa awal kehidupan anak merupakan masa terpenting dalam rentang kehidupan seseorang anak.Pada masa ini pertumbuhan otak sedang mengalami perkembangan yang sangat pesat (eksplosif). Perkembangan pada tahun-tahun pertama sangat penting menentukan kualitas anak di masa depan. Perkembangan intelektual anak usia 4 tahun telah mencapai $50 \%$, pada usia 8 tahun mencapai $80 \%$ dan pada saat mencapai sekitar 18 tahun perkembangan telah mencapai $100 \%$.

Pendidikan bukan hanya bertujuan menciptakan manusia-manusia cerdas di bidang sains dan teknologi, cerdas di sisi intelektualitasnya, tetapi juga harus mampu menumbuhkembangkan sikap dan semangat keagamaan yang terbuka (inklusif), karena keduanya tidak dapat dipisahkan.Keduanya diharapkan dapat tumbuh dan berkembang secara bersama-sama agar terjadi keseimbangan hidup dalam diri anak didik. YB. Mangunwijaya (2009: 13)

Kompetensi keimanan adalah kemampuan anak pendidik dalam memahami dan mengamalkan nilai-nilai keimanan agar memiliki keperibadian yang tangguh, ketangguhan ini selanjutnya akan merefleksikan dalam pola pikir dan prilakunya dalam melaksanakan aktivitas pendidikan dan pembelajaran. YB. Mangunwijaya (2009: 13)

Anak yang memiliki kepribadian Islam adalah anak yang memiliki kelebihan dalam banyak hal, sehingga mereka bisa dikatakan sebagai anak unggul.Anak unggul adalah anak yang sholeh/sholehah, cerdas, sehat dan pemimpin. Anak unggul adalah anak yang terarah cara berpikir dan bersikapnya berdasarkan akidah Islam dan memiliki kemampuan serta keterampilan yang bisa ia gunakan untuk kehidupannya sendiri maupun kehidupan bermasyarakat dan bernegara, sehingga mereka siap menjadi pemimpin di masa mendatang yang akan memberi sumbangan yang besar bagi kemajuan peradaban suatu bangsa di mana mereka hidup.

Penanman nilai aqidah sangat penting diinternalisasikan pada diri anak, karena pendidikan berbasis aqidah sangat penting untuk meningkatkan keimanan anak sekaligus 
sebagai pembentukan sikap anak. Karena aqidah seseorang akan berpengaruh pada akhlak anak.

Penyebab timbulnya kenakalan remaja atau anak-anak adalah salah satunya kurangnya pendidikan agama yang diberikan di dalam keluarga (orang tua). Yang dimaksud pendidikan agama di sini adalah penanaman jiwa agama sejak anak masih kecil dengan jalan membiasakan mereka untuk melakukan sifat-sifat dan kebiasaan yang baik, misalnya menghargai hak milik orang lain, selalu berkata terang, benar, dan jujur, suka menolong, memaafkan kesalahan orang lain, dan sebagainya. Yusak Burhanudin (1999: 86)

SDN Ranto Panyangmerupakan salah satu sekolah yang ada menerapkan pendidikan berbasis aqidah, yaitu dengan cara menginternalisasikan nilai-nilai keimanan dalam diri anak dalam proses pengajaran, contohnya seperti pada materi organ tubuh guru menjelaskan tentang mata itu merupakan ciptaan Allah yang harus disyukuri dan sebagainya.Proses internalisasi nilai-nilai aqidah sangat penting bagi anak sekolah dasar, terlebih lagi pada anak kelas I SD yang jiwanya masih bersih dan sangat mudah dipengaruhi oleh hal-hal yang tidak baik.

Berdasarkan hal tersebut mendorong penulis untuk membahasnya dengan judul "Implementasi Pendidikan Berbasis Aqidah pada Murid SDN Ranto Panyang Kecamatan Meureubo Kabupaten Aceh Barat”.

\section{KAJIAN TEORI}

Menurut Moh. Roqib, pendidikan berbasis aqidah adalah mengintegrasikan unsure religius yang transcendental dengan setiap cabang ilmu menjadi hal yang tak terelakkan. Sebab jika kedua hal tersebut tidak terintegrasikan dengan baik maka akan menimbulkan bias pemikiran yang pada gilirannya akan mengakibatkan rasa kebingungan pada peserta didik. Moh. Roqib (2009: 78)

Sedangkan menurut Syaikh Fuhaim Mustafa, pendidikan berbasis aqidah adalah sebuah pendekatan religi terhadap pendidikan, yang artinya suatu ajaran religi dari agama tertentu dijadikan sumber inspirasi untuk menyusun teori atau konsep-konsep pendidikan yang dapat dijadikan landasan untuk melaksanakan pendidikan.Ajaran religi yang berisikan kepercayaan dan nilai-nilai kehidupan, dapat dijadikan sumber dalam menentukan 
tujuan pendidikan, materi pendidikan, metode, bahkan sampai pada jenis-jenis pendidikan. Syaikh Fuhaim Mustafa 2009: 10)

Dari uraian di atas dapat disimpulkan bahwa pendidikan berbasis aqidah adalah proses pembelajaran dengan pendekatan internalisasi nilai-nilai pokok kepercayaan atau keyakinan hati seorang muslim yang bersumber ajaran Islam yang wajib dipegangi oleh setiap muslim sebagai sumber keyakinan keimanan kepada Allah, dan ibadah kepada Allah.

\section{METODE}

\section{Jenis data yang dibutuhkan}

Jenis data yang dibutuhkan dalam penelitian ini sangat penting ditentukan karena akan mempengaruhi hasil penelitian yang diperoleh di lapangan. Adapun jenis data yang dibutuhkan yaitu data primer dan data skunder. Data primer adalah data yang sangat diutamakan dan penting dalam proses penulisan skripsi ini seperti pendapat para ahli terutama dalam bidang prestasi belajar yang bersumber dari buku-buku, hasilwawancara dan angket. Data skunder yaitu data pendukung dapat diperoleh dari dokumentasi dan lain-lain yang dianggap perlu, sehingga dapat mendukung data primer yang diperlukan dalam penelitian ini.

\section{Subyek Penelitian}

Menurut Suharsimi Arikunto, subyek adalah seseorang atau lebih yang sengaja dipilih oleh peneliti guna dijadikan nara sumber data yang dikumpulkan. Suharsmi Arikunto (2009: 103) Dasar pertimbangan memilih orang tersebut adalah dianggap menguasai bidang permasalah dan tugas-tugasnya. Sedangkan yang akan dijadikan sebagai subyek dalam penelitian ini adalah:

a. Dewan Guru terutama guru Pendidikan Agama Islam yang membimbing para murid di SDN Ranto Panyang.

b. Murid SDN Ranto Panyang sebagai responden dalam penelitian ini.

\section{Teknik Pengumpulan Data}

a. Wawancara

Wawancara adalah sebuah dialog yang dilakukan oleh pewawancara (interviewer) untuk memperoleh informasi dari terwawancara (interviewe). Suharsimi Arikunto (2002: 132) 
Hasil wawancara itu berupa jawaban responden dan informan terhadap permasalahan penelitian dan di jadikan data dalam penulisan skripsi ini. Dalam hal ini, penulis menggunakan wawancara langsung dengan guru SDN Ranto Panyang.

b. Angket

Angket adalah "sejumlah pertanyaan tertulis yang digunakan untuk memperoleh informasi dari responden dalam arti laporan tentang pribadinya, atau hal-hal yang ia ketahui". Suharsimi Arikunto (2002: 128)Angket dibagikan penulis secara langsung kepada responden, jadi responden tinggal menjawab dengan memilih jawaban yang paling tepat dengan apa yang diketahuinya. Angket ini ditujukan kepada murid.

c. Metode Dokumentasi

Menurut Suharsimi Arikunto meteode dokumentasi yaitu "mencari data mengenai halhal atau variabel yang berupa catatan, transkrip, buku, surat kabar, majalah, prasasti, lengger, agenda, dan sebagainya". Suharsimi Arikunto (2002: 128)Metode ini penulis gunakan sebagai penguat data yang diperoleh di dalam meneliti tentang pendekatan pendidikan berbasis aqidah pada murid SDN Ranto Panyang, jadi metode dokumentasi yang dipakai oleh peneliti ini adalah untuk melengkapi data lapangan yang diperoleh dari metode angket dan interview.Dalam hal ini dipergunakan untuk mengumpulkan data mengenai pendekatan pendidikan berbasis aqidah.

\section{Teknik Pengolahan dan Analisis Data}

Analisis data adalah proses mengatur urutan-urutan data, mengorganisasikan dalam suatu kategori dan satuan uraian dasar. Ia membedakan dengan penafsiranan, yaitu memberikan arti yang signifikan terhadap analisis, menjelaskan pola uraian, dan mencari hubungan diantara dimensi-dimensi uraian. Setelah data terkumpul dan telah dianggap representatif bagi sebuah karya ilmiah, maka tahapan berikutnya adalah tehnik analisa data. Dalam teknik analisis data, penulis mengolah hasil wawancara dan mendeskripsikannya, menganalisa dan menyimpulkannya. Kemudian data yang diperoleh dari angket dilakukan analisis melalui tabulasi data dengan rumus statistik sederhana yaitu:

$\mathrm{P}=\mathrm{F} / \mathrm{N} \times 100$

\section{HASIL DAN PEMBAHASAN}

1. Penerapan Pendidikan Berbasis Aqidah pada Siswa SDN Ranto Panyang 
Dalam proses pendidikan yang diberikan guru tidak hanya berfokus pada materi pokok saja tapi perlu juga meninternalisasi nilai-nilai aqidah supaya karakter anak didik terbentuk dengan baik. Karena perilaku anak merupakan implementasi dari aqidah dalam segala bentuk perilaku.

Rafi'ah sebagai wali kelas I megatakan bahwa dalam melaksanakan pembelajaran saya sering menerapkan pendidikan aqidah, karena walaupun bukan pelajaran agama yang saya ajarkan tapi internalisasi nilai-nilai aqidah sering saya terapkan dalam pembelajaran, supaya sikap anak-anak lebih baik. Misalnya dalam pelajaran matematika yang saya ajarkan sering saya kaitkan dengan pendidikan aqidah seperti dalam materi menghitung, saya menjelaskan dan menyanyikan dengan murid "nol hitung nol, nol tidak ada, satu hitung satu, satu Tuhan saya, dua hitung dua, dua mata saya, tiga hitung tiga, tiga roda becak, empat hitung empat, empat roda mobil, lima hitung lima, lima rukun Islam, enam hitung enam, enam rukun iman, tujuh hitung tujuh, tujuh hari sekolah". Dan juga lagu menghitung dengan pendekatan rukun iman yaitu "Rukun iman enam perkara, yang pertama iman kepada Allah, yang kedua Malaikat-Nya, yang ketiga Rasul-rasul-Nya, yang keempat Kitab-kitab-Nya, yang kelima hari Qiamat, yang keenam Qadha dan Qadar Semua datang dari Allah”. Rafi'ah (2021)

Rafi'ah melanjutkat pernyataannya bahwa ia ketika mengajar pelajaran IPA juga sering mengaitkan materi IPA dengan aqidah yang baik kepada anak-anak, seperti pada materi organ tubuh menjelaskan mata itu merupakan ciptaan Allah yang harus disyukuri dan sebagainya. Rafi'ah (2021)

Dari wawancara di atas dapat disimpulkan bahwa dalam pengajaran sering diterapkan pendidikan dengan pendekatan aqidah, tidak pada pelajaran agama saja ditanamkan nilai-nilai aqidah pada diri anak tapi juga pada pelajaran matematika dan IPA juga diterapkan pendekatan aqidah disesuaikan dengan materinya.

Berdasarkan data-data yang diperoleh melalui angket yang disebarkan pada sejumlah responden (27 murid) sebagai sampel yang kemudian dikumpulkan serta dianalisa dengan rumus distribusi frekuensi.Untuk lebih jelasnya berikut hasil angket yang penulis sebarkan di lapangan tentang penerapan pendidikan berbasis aqidah.

Tabel 4.4. Guru menghubungkan materi pelajaran dengan nilai-nilai aqidah

\begin{tabular}{clcc}
\hline No & Alternatif Jawaban & $\boldsymbol{f}$ & $\mathbf{\%}$ \\
\hline 1 & Sering Sekali & 7 & 25,93 \\
\hline 2 & Sering & 10 & 37,04 \\
\hline
\end{tabular}




\begin{tabular}{clcc}
\hline 3 & Kadang-Kadang & 6 & 22,22 \\
\hline 4 & Tidak Pernah & 4 & 14,81 \\
\hline & Jumlah & $\mathbf{2 7}$ & $\mathbf{1 0 0}$ \\
\hline
\end{tabular}

Dari tabel diatas dapat diketahui bahwa guru menghubungkan materi pelajaran dengan nilai-nilai keagamaan. Kesimpulan ini dapat didukung dengan jawaban responden memilih sering sekali yang berjumlah 25,93\%, memilih jawaban sering 37,04\% dan yang menjawab kadang-kadang $22,22 \%$ dan $14,81 \%$ responden yang menjawab tidak pernah. Maka analisa data pada tabel di atas, bahwa mayoritas responden menyatakan guru sering menghubungkan materi pelajaran dengan nilai-nilai keagamaan.

Dalam hal ini Rafi'ah mengatakan bahwa, saya dalam mengajar sering menghubungkan materi pelajaran yang saya ajarkan dengan nilai-nilai keagamaan, karena apapun materi pelajaran yang diajarkan pasti bisa kita hubungkan dengan nilai-nilai keagamaan supaya anak mampu menerapkan prilaku keagamaan dalam kehidupan seharihari. Rafi'ah (2021)

Penerapan pendidikan berbasis aqidah penting diterapkan dalam materi pelajaran dengan menghubungkan nilai-nilai aqidah yang sesuai dengan materi yang diajarkan.Menghubungkan materi pelajaran dengan nilai-nilai aqidah ada pengaruh positif bagi murid.

Tabel 4.5. Guru menjelaskan nilai-nilai keagamaan dalam materi pelajaran

\begin{tabular}{clcc}
\hline No & \multicolumn{1}{c}{ Alternatif Jawaban } & $\boldsymbol{f}$ & $\mathbf{\%}$ \\
\hline 1 & Sering Sekali & 8 & 29,63 \\
\hline 2 & Sering & 10 & 37,04 \\
\hline 3 & Kadang-Kadang & 6 & 22,22 \\
\hline 4 & Tidak Pernah & 3 & 11,11 \\
\hline & Jumlah & $\mathbf{2 7}$ & $\mathbf{1 0 0}$ \\
\hline
\end{tabular}

Dari tabel diatas dapat diketahui bahwa guru menjelaskan nilai-nilai keagamaan dalam materi pelajaran. Kesimpulan ini dapat didukung dengan jawaban responden memilih sering sekali yang berjumlah $29,63 \%$, memilih jawaban sering $37,04 \%$ dan yang menjawab kadang-kadang $22,22 \%$ dan $11,11 \%$ responden yang menjawab tidak pernah. Maka analisa data pada tabel di atas, bahwa mayoritas responden menyatakan guru sering menjelaskan nilai-nilai keagamaan dalam materi pelajar.

Dalam hal ini Marlina mengatakan bahwa, dalam pembelajaran saya menerapkan sistem pendidikan berbasis aqidah dengan menjelaskan nilai-nilai aqidah yang ada Suroto |Implementasi pendidikan berbasis Aqidah pada siswa SD Ranto Panyang Kecamatan Meureubo Kabupaten Aceh Barat | 162 
hubungannya dengan materi pembelajaran sehingga anak-anak akan lebih memahami/ meyakini tentang materi tersebut. Marlina (2021)

Dari uraian di atas dapat disimpulkan bahwa Penerapan Pendidikan Berbasis Aqidah pada Siswa Kelas I SDN Ranto Panyang berjalan dengan baik. Penerapan pendidikan berbasis aqidah dengan menghubungkan materi pelajaran dengan nilai-nilai aqidah, dan menjelaskan nilai-nilai aqidah itu.

Nilawati mnegatakan bahwa, dalam pengajaran ia sering menghubungkan materi pelajaran dengan nilai aqidah, dengan tujuan agar dapat mempengaruhi sikap anak karena kalau nilai-nilai keimanan sudah tertanam dalam diri anak maka dengan sendirinya sikap akan lebih baik. Nilawati (2021)

Pembentukan karakter anak dapat ditanamkan dengan mengiternalisasi nilai-nilai aqidah yang baik dalam jiwa anak, karena apabila aqidah/ keimanan anak sudah tertanam dengan baik maka perilaku anak dengan sendirinya akan baik.

Tabel 4.10. Penerapan pendidikan berbasis aqidah dapat mempengaruhi sikap murid

\begin{tabular}{|c|c|c|c|}
\hline No & Alternatif Jawaban & $f$ & $\%$ \\
\hline 1 & Sering Sekali & 10 & 37,04 \\
\hline 2 & Sering & 8 & 29,63 \\
\hline 3 & Kadang-Kadang & 6 & 22,22 \\
\hline \multirow[t]{2}{*}{4} & Tidak Pernah & 3 & 11,11 \\
\hline & Jumlah & 27 & 100 \\
\hline
\end{tabular}

Dari tabel diatas dapat diketahui bahwa penerapan pendidikan berbasis aqidah dapat mempengaruhi sikap murid. Kesimpulan ini dapat didukung dengan jawaban responden memilih sering sekali yang berjumlah 37,04\%, memilih jawaban sering 29,63\% dan yang menjawab kadang-kadang $22,22 \%$ dan $11,11 \%$ responden yang menjawab tidak pernah. Maka analisa data pada tabel di atas, bahwa lebih dari separuh responden menjawab penerapan pendidikan berbasis aqidah dapat mempengaruhi sikap murid.

Tabel 4.11. Penerapan pendidikan berbasis aqidah dapat mempengaruhi motivasi belajar

\begin{tabular}{clcc}
\hline No & Alternatif Jawaban & $\boldsymbol{f}$ & $\mathbf{\%}$ \\
\hline 1 & Sering Sekali & 8 & 29,63 \\
\hline 2 & Sering & 9 & 33,33 \\
\hline 3 & Kadang-Kadang & 6 & 22,22 \\
\hline 4 & Tidak Pernah & 4 & 14,81 \\
\hline & Jumlah & $\mathbf{2 7}$ & $\mathbf{1 0 0}$ \\
\hline
\end{tabular}


Dari tabel diatas dapat diketahui bahwa penerapan pendidikan berbasis aqidah dapat mempengaruhi motivasi belajar. Kesimpulan ini dapat didukung dengan jawaban responden memilih sering sekali yang berjumlah 29,63\%, memilih jawaban sering 33,33\% dan yang menjawab kadang-kadang 22,22\% dan 14,81\% responden yang menjawab tidak pernah. Maka analisa data pada tabel di atas, bahwa lebih dari separuh responden menjawab penerapan pendidikan berbasis aqidah dapat mempengaruhi motivasi belajar.

Kartini mengatakan bahwa penerapan pendidikan berbasis aqidah itu merupakan motivasi belajar murid. Karena motiasi ada yang dalam bentuk spiritual yaitu dengan menamkan keyakinan bahwa belajar dengan niat ibadah akan menjadi nilai ibadah, sehingga anak-anak akan termotivasi. Kartini (2021)

Selain motivasi dalam memberi reward kepada anak, ada juga motivasi spiritual yang diberikan kepada anak. Pendidikan berbasis aqidah merupakan bentuk motivasi spiritual bagi anak, dengan adanya motivasi spiritual anak akan lebih cendrung suka pada kegiatan keagamaan.

Tabel 4.12. penerapan pendidikan berbasis aqidah dapat mempengaruhi kualitas keimanan

\begin{tabular}{clcc}
\hline No & \multicolumn{1}{c}{ Alternatif Jawaban } & $\boldsymbol{f}$ & $\mathbf{\%}$ \\
\hline 1 & Sering Sekali & 8 & 29,63 \\
\hline 2 & Sering & 9 & 33,33 \\
\hline 3 & Kadang-Kadang & 6 & 22,22 \\
\hline 4 & Tidak Pernah & 4 & 14,81 \\
\hline & Jumlah & $\mathbf{2 7}$ & $\mathbf{1 0 0}$ \\
\hline
\end{tabular}

Dari tabel diatas dapat diketahui bahwa penerapan pendidikan berbasis aqidah dapat mempengaruhi kualitas keimanan. Kesimpulan ini dapat didukung dengan jawaban responden memilih sering sekali yang berjumlah 29,63\%, memilih jawaban sering 33,33\% dan yang menjawab kadang-kadang $22,22 \%$ dan $14,81 \%$ responden yang menjawab tidak pernah. Maka analisa data pada tabel di atas, bahwa lebih dari separuh responden menjawab penerapan pendidikan berbasis aqidah dapat mempengaruhi kualitas keimanan.

Cut Rosmanizar mengatakan bahwa dengan adanya penerapan pendidikan berbasis aqidah dapat mempengaruhi kualitas iman anak. Anak-anak tidak berbohong, tidak mengganggu kawan, tidak mengambil punya kawan karena keimanan yaitu takut pada dosa. Cut Rosmanizar(2021) 
Dalam pembinaan aqidah anak secara otomatis akan berpengaruh besar pada sikap anak, makanya cara yang tepat membentuk sikap anak adalah menanamkan nilai keimanan pada diri anak sehingga akan timbul kesadaran anak yang pada dasarnya dalam keadaan suci sangat mudah untuk dibentuk sikapnya yaitu dengan menjaga kefitrahan anak dengan pendidikan berbasisi spiritual.

Dari uraian di atas dapat disimpulakan bahwa penerapan pendidikan berbasis aqidah pada murid kelas I SDN Ranto Panyangsangat efektif karena dapat mempengaruhi sikap baik murid, meningkatkan motivasi belajar, dan meningkatnya kualitas iman.

\section{PENUTUP}

Dari hasil penelitian yang telah dilakukan, dapat diambil kesimpulan Penerapan Pendidikan Berbasis Aqidah pada Siswa SD Ranto Panyang Kecamatan Meureubo Kabupaten Aceh Barat berjalan dengan baik. Penerapan pendidikan berbasis aqidah dengan menghubungkan materi pelajaran dengan nilai-nilai aqidah, dan menjelaskan nilai-nilai aqidah itu dan Penerapan pendidikan berbasis aqidah pada murid kelas I SDN Meunasah Ara relatif efektif karena dapat mempengaruhi sikap baik murid, meningkatkan motivasi belajar, dan meningkatnya kualitas iman.

\section{DAFTAR PUSTAKA}

Moh.Roqib. 2009. Ilmu Pendidikan Islam, Pengembangan Pendidikan Integratif di Sekolah, Keluarga dan Masyarakat, Yogyakarta: LKiS Pelangi Aksara

Mustafa, Syaikh Fuhaim. 2009. Kurikulum Pendidikan Anak Muslim, terjemahan Wafi Marzuqi AmmarSurabaya: Pustaka Elba

Suharsimi Arikunt. 2002. Prosedur Penelitian,Suatu Pendekatan Praktek, Jakarta: Rineka Cipta

Syaikh Muhammad bin Shalih al-Utsaimin. 2007. Syarah Hadits Arba'in, Jakarta: Ummul Qura

Undang-Undang Republik Indonesia Nomor 20 Tahun 2003 tentang Sistem Pendidikan Nasional, Jakarta: Departemen: Departemen Pendidikan Nasional.

YB. Mangunwijaya. 2009.Menumbuhkan Sikap Religiusitas Anak, dikutip langsung oleh Heribertus Joko Warwanto, et al., Pendidikan Religiositas-Gagasan, Isi dan Pelaksanaanya Yogyakarta: Kanisius

Yusak Burhanudin. 1999. Kesehatan Mental, Bandung: Pustaka Setia 
Hasil wawancara dengan Rafi'ah Wali Kelas I SDN Ranto Panyang pada tanggal 5 September 2021

Hasil wawancara dengan Marlina (guru SDN Ranto Panyang) pada tanggal 5 September 2021

Hasil wawancara dengan Nilawati (guru SDN Ranto Panyang) pada tanggal 8 September 2021 ,

Hasil wawancara dengan Kartini (guru SDN Ranto Panyang) pada tanggal 11 September 2021

Hasil wawancara dengan Cut Rosmanizar (guru SDN Ranto Panyang) pada tanggal 11 September 2021 